\title{
Ecological impacts of feral pigs in the Hawaiian Islands
}

\author{
Sérgio L. G. Nogueira-Filho · Selene S. C. Nogueira · José M. V. Fragoso
}

Published online: 24 July 2009

(C) Springer Science+Business Media B.V. 2009

\section{Erratum to: Biodivers Conserv DOI 10.1007/s10531-009-9680-9}

The Author would like to add the following paragraph on page 4 after the sentence ".... Proper controls should consider animal behavior and spatial components such as pig home range size, movements, and plant distribution patterns.

"Another potentially confounding factor is that large grazing and/or browsing ducks and geese where once common to the islands but are now extinct or greatly reduced in population size (Paxinos et al. 2002). One of these geese species was four times the size of a Canada goose (Branta canadensis) to which they were closely related. The nene (Branta sandvicensis) is extant but populations and range have been severely reduced. These were not wetland dwellers; instead they inhabited a variety of habitat types (Paxinos et al. 2002). Canada geese can strongly affect native plant community composition and reduce the abundance of native species (Haramis and Kearns 2007). The extinction of the Hawaiian species probably severely altered Hawaiian plant communities and populations, possibly in a manner analogous to what was described by Dirzo and Miranda (1990) for tropical plant communities when native mammalian grazers and browsers are extirpated. They described a significant reduction in plant species diversity in areas missing large vertebrate browsers and grazers and a shift to increased numerical dominance by a few species. Understanding the ecological significance of pig impacts on "native" biotic communities may thus be further confounded by the impacts generated by the extinction of native flightless geese and ducks."

The online version of the original article can be found under doi:10.1007/s10531-009-9680-9.

S. L. G. Nogueira-Filho $(\bowtie) \cdot$ S. S. C. Nogueira

Applied Ethology Laboratory, Universidade Estadual de Santa Cruz, Rod. Ilhéus Itabuna km 16, Ilhéus, BA 45662-000, Brazil

e-mail: slgnogue@uesc.br

S. L. G. Nogueira-Filho · S. S. C. Nogueira - J. M. V. Fragoso

Department of Botany, University of Hawaii at Manoa, 3190 Maile Way, St. John Lab 101, Honolulu, HI 96822, USA 
In the Conclusion part on page no. 5 the Author would like to replace the following sentence "Despite the many potential negative impacts to native biota and ecosystems generated by pig activities, eliminating the pig from Hawaiian Islands remains difficult if not impossible, mostly because many Hawaiians further value it for its cultural, and religious significance (Stone 1985).” with

"Despite the many potential negative impacts to native biota and ecosystems generated by pig activities, eliminating the pig from Hawaiian Islands remains difficult if not impossible, mostly because many Hawaiians value the pig for its recreational value (Stone 1985), while indigenous Hawaiians further value it for its cultural and religious significance (Mueller-Dombois and Wirawan 2005)."

Also the following references are to be added in the References:

1. Dirzo R, Miranda A (1990) Contemporary Neotropical defaunation and forest structure, function, and diversity—a sequel to John Terborgh. Conserv Biol 4:444-447

2. Haramis GM, Kearns GD (2007) Herbivory by resident geese: the loss and recovery of wild rice along the tidal patuxent river. J Wildl Manag 71:788-794

3. Mueller-Dombois D, Wirawan N (2005) The Kahana Valley Ahupua'a, a PABITRA study site on O`ahu, Hawaiian Islands. Pac Sci 59:293-314

4. Paxinos EE, James HF, Olson SL, Sorenson MD, Jackson J, Fleischer RC (2002) mtDNA from fossils reveals a radiation of Hawaiian geese recently derived from the Canada goose (Branta canadensis). Proc Natl Acad Sci USA 99:1399-1404 